\title{
Multifunctional System Polyaniline-Decorated ZIF-8 Nanoparticles as a New Chemo-Photothermal Platform for Cancer Therapy
}

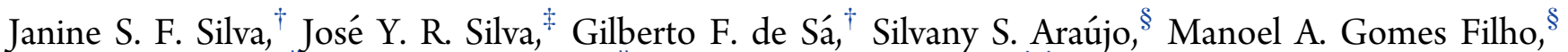

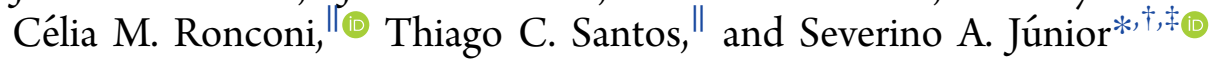

${ }^{\dagger}$ Fundamental Department of Chemistry and ${ }^{\ddagger}$ Materials Science Program, Federal University of Pernambuco, 50670-901 Recife, Pernambuco, Brazil

${ }^{\S}$ Department of Sciences Biological, Federal Rural University of Pernambuco, 52171-900 Recife, Pernambuco, Brazil

"Department of Inorganic Chemistry, Fluminense Federal University Valonguinho, 24.020-150 Niterói, Rio de Janeiro, Brazil

\section{Supporting Information}

ABSTRACT: Polyaniline-decorated ZIF-8 nanoparticles (nPANI@nZIF-8) were easily synthesized and employed as a multifunctional system for the delivery of the antitumor drug 5-fluorouracil (5-FU). Because of the storage ability of the network ZIF-8, 68\% of the total amount of the 5-FU drug was released at $\mathrm{pH}$ 5.2. The system exhibits absorption in the near-infrared (NIR) region and can be used in the photothermal therapy owing to the presence of nPANI, which has a strong NIR uptake. This absorption causes local hyperthermia by aiding in the diffusion of the drug molecules contained by the polymer into nPANI@nZIF-8/5-FU achieving a greater release of the 5 -FU drug, about $80 \%$ activated by an NIR laser $(\lambda=980 \mathrm{~nm})$. This hyperthermia reached about $70{ }^{\circ} \mathrm{C}\left(200 \mu \mathrm{L}, 1 \mathrm{mg} \mathrm{mL}{ }^{-1} \mathrm{nPANI} @\right.$ nZIF-8), which was directly proportional to the concentration of the material. Therefore, our work can aid in the construction of new chemophotothermal platforms that may be employed in cancer therapy.

\section{INTRODUCTION}

Multifunctional systems have attracted a lot of attention and are being developed to provide better and cheaper alternatives in the treatment of cancer. ${ }^{1-5}$ A chemo-photothermal multifunctional system has achieved prominence in recent years. This method consists of a nanomaterial as the carrier for drug delivery and a nanomaterial that has photothermal conversion efficiency. ${ }^{6-8}$

The photothermal therapy (PTT) uses materials that absorb and convert energy from near-infrared (NIR) light into thermal energy causing localized hyperthermia. ${ }^{9}$ This therapy can be used to treat tumors. The irradiation at the NIR frequency can penetrate the tissues with sufficient intensity, as well as with spatial accuracy. Soft tissues and blood are relatively transparent in the $700-1100 \mathrm{~nm}$ region. PTT has the advantage of being minimally invasive, with a minimal damage to healthy tissues. ${ }^{10}$ Reports on the use of metals as photothermal agents are already widespread in the literature, where metals are mainly combined with other materials. ${ }^{11-14}$ However, these metals are of high cost and exhibit low photostability under long-term laser irradiation. ${ }^{15}$ Polymers are among the alternative materials in the use of PTT, particularly polypyrrole $^{16-18}$ and polyaniline (PANI). ${ }^{15,19,20}$ PANI has wide applications because of chemical stability, low cost, and easy polymerization synthesis. It also exhibits excellent dispersibility in water, high NIR photothermal conversion efficiency, and low toxicity to living systems. ${ }^{15,21}$ For these reasons, PANI was chosen as the photothermic agent for this work. Furthermore, nanostructured PANI (nPANI) exhibits a greater surface area and higher interactions of the polymer with the medium.

The drug carrier nanomaterial must have a structure with large surface area and high pore volume. The material usually employed for this purpose is the mesoporous silicas. ${ }^{22-24}$

The other type of material that has the same profile and is being widely used as a drug carrier is the class of metal organic frameworks (MOFs). MOFs are a coordination network with organic ligands containing potential voids formed between a metal and an organic binder bonded by the coordinate bonds, generally, in two or three dimensions. ${ }^{25-27}$

Previously, our group has used the MOF ZIF-8 for the incorporation of the drug doxorubicin (DOX; a load $0.049 \mathrm{~g}$ of DOX/g dehydrated ZIF-8). DOX was released in a progressive manner with $66 \%$ of the drug released after 30 days. ${ }^{28}$ Another work concerned the use of molecular docking to confirm the utility of the MOF $\left[\mathrm{Zn}(\mathrm{BDC})\left(\mathrm{H}_{2} \mathrm{O}\right)_{2}\right]_{n}$ in the loading of some drugs. The procedure was able to distinguish between the bad (gentamicin) and good guest (ibuprofen, methylene blue, and

Received: May 20, 2018

Accepted: September 13, 2018

Published: September 27, 2018 
amoxicillin) drug candidates for immobilization in the $\left[\mathrm{Zn}(\mathrm{BDC})\left(\mathrm{H}_{2} \mathrm{O}\right)_{2}\right]_{n}$ framework, validated via experimental measurements. ${ }^{29}$

In medicine, studies have explored the application of MOFs in a nanometric scale (nMOFs) to enhance the interaction with cancerous cells because of smaller particle size. ${ }^{30}$ Some materials have already been incorporated in the nMOFs as, for example, photosensitizers, contrast agents, magnetic materials, luminescence materials, and drugs. These materials demonstrated potential clinical applications such as biomedical imaging, sensing, photodynamic therapy (PDT), and drug delivery in cancer therapy. ${ }^{2,6,8,18}$ The nMOF used in this work was part of the zeolitic imidazolate framework (ZIF) group. ZIF-8 has the Zn metal coordinated by the 2-methyl imidazole linker. It exhibits chemical and thermal stabilities, harmony and high pore availability, high cubic crystalline symmetry, relatively low density, large surface area, and excellent water stability. ${ }^{31-34}$

The ZIF-8 nanoparticles (nZIF-8) have already been widely employed in cancer therapy as the carrier in chemophotothermal multifunctional systems.

Tian et al. produced two chemo-photothermal multifunctional systems involving nZIF-8. The first work synthesized ZIF-8 with graphene oxide (GO) nanocrystals with the encapsulation of fluorescein simultaneously. A controlled release of fluorescein by the action of $\mathrm{pH}(98 \%$ at $\mathrm{pH}=4.5)$ was obtained. An $808 \mathrm{~nm}, 2.5 \mathrm{~W} \mathrm{~cm}^{-2}$, NIR laser was used for $3 \mathrm{~min}$ on the ZIF-8/GO material, and the temperature of the nanocrystals was raised from 30 to $46.5{ }^{\circ} \mathrm{C}$. There were also significant decreases in the cell viability (40 and $21 \%$ ) when the cells were cultured with fluorescein-ZIF-8/GO, 50 and 100 $\mu \mathrm{g} / \mathrm{mL}$, respectively, for $8 \mathrm{~h}$ and then irradiated. ${ }^{4}$ In the second work, nZIF-8 was proposed as a DOX drug nanocarrier and the embedded graphene quantum dots (GQDs) as local photothermal seeds, exhibiting a $\mathrm{pH}$-responsive DOX release behavior (80\% release in the $\mathrm{pH} 4.5$ ). The DOX-ZIF-8/GQD suspension $\left(5 \mathrm{mg} \mathrm{mL}^{-1}\right)$ was irradiated with an $808 \mathrm{~nm}$ laser at a power of $2.0 \mathrm{~W} \mathrm{~cm}^{-2}$ for $10 \mathrm{~min}$ and resulted in an increase from 30 to $49.5{ }^{\circ} \mathrm{C}$. In vitro, the cells were treated for $8 \mathrm{~h}$ with the nanoparticles and were followed by NIR irradiation at 808 $\mathrm{nm}$ for $3 \mathrm{~min}$ at $2.5 \mathrm{~W} \mathrm{~cm}^{-2}$, with the cell viability decreasing by $18 \% .^{35}$

Yang et al. also produced a chemo-photothermal multifunctional system involving nZIF-8. They reported on a new nanocomposite based on ZIF-8, with Pd-Au nanoparticles and the DOX drug encapsulated. ${ }^{2}$ At $\mathrm{pH}=4$, this achieved a $65.2 \%$ of DOX release within $600 \mathrm{~min}$. The sample DOX/Pd@Au@ ZIF-8 (0.0375 $\left.\mathrm{mg} \mathrm{mL}^{-1}\right)$ after irradiation with an NIR laser treatment of $780 \mathrm{~nm}\left(2.1 \mathrm{~W} \mathrm{~cm}^{-2}\right)$ for $10 \mathrm{~min}$ achieved a gradual increase of temperature $\left(\sim \Delta 17{ }^{\circ} \mathrm{C}\right)$. The cells pretreated with DOX/Pd@Au@ZIF-8 $(80 \mu \mathrm{g} / \mathrm{mL})$ for $24 \mathrm{~h}$ and then irradiated by the NIR laser for $10 \mathrm{~min}$ decreased the viability of cancer cells by $11 \%$.

Other types of multifunctional systems involving nZIF-8 have been reported. Yang and collaborators combined PTT and PDT. The temperature of HeLa cells incubated with $\mathrm{Fe}_{3} \mathrm{O}_{4} / \mathrm{ZIF}-8-5 \mathrm{~mL}-\mathrm{Au}_{25}$ increased to about $60^{\circ} \mathrm{C}$ after $10 \mathrm{~min}$ of irradiation, and most of the cells incubated with $\mathrm{Fe}_{3} \mathrm{O}_{4} / \mathrm{ZIF}$ $8-\mathrm{Au}_{25}$ after two types of stimuli (NIR light and magnet remote control) were killed, presenting less than $15 \%$ cell viability. ${ }^{11}$ Chowdhuri et al. developed a multifunctional nanomaterial, $\mathrm{NaYF}_{4}: \mathrm{Yb}^{3+}$ and $\mathrm{Er}^{3+}$, upconverting nanoparticles (UCNPs), encapsulated by nZIF-8, folic acid functionalized (UCNPs@
ZIF-8/FA), and loaded with the drug 5-FU. The UCNP@ZIF$8 /$ FA nanomaterial was used simultaneously as the carrier and in cell images because of its luminescent properties. The drug 5-fluorouracil (5-FU) was absorbed into the UCNP@ZIF-8/ FA nanocomposites $\left(685 \mathrm{mg} \cdot \mathrm{g}^{-1}\right)$, and the $\mathrm{pH}$-responsive drug release was observed ( $82 \%$ at $\mathrm{pH} 5.5) .^{36}$

In this work, we report on the effective and rapid synthesis of PANI-decorated ZIF-8 nanoparticles (nPANI@nZIF-8)/5$\mathrm{FU}$ as a new multifunctional and synergistic, $\mathrm{pH}$-sensitive system for the chemo-photothermal treatment of cancer.

\section{RESULTS AND DISCUSSIONS}

Employment of ZIF-8 as a support material for PANI nanoparticles and a carrier for 5-FU antitumor, in the form of a single multifunctional system, has provided a new strategy for chemo-photothermal cancer therapy.

2.1. Synthesis and Optimization of nPANI@nZIF-8. The optimization of nPANI@nZIF-8 synthesis was successful as a chemo-photothermal system. The synthesized nanomaterial followed the adapted template described in the literature and reported in the experimental procedure. ${ }^{37}$ Initially, $50 \mathrm{v} / \mathrm{v}$ $\%$ of the PANI solution for the in situ synthesis of network nZIF-8 was used.

The X-ray diffraction (XRD) analysis (see Figure S1), of the nanomaterial obtained, only showed the semicrystallinity of the emeraldine PANI already reported in the literature $\left(2 \theta=20^{\circ}\right.$ and $25^{\circ}$ ), exhibiting an excessive amount of PANI nanoparticles which made the nZIF-8 lattice imperceptible. ${ }^{38-40}$

This prominent amount of nPANI was confirmed by the $\mathrm{N}_{2}$ adsorption-desorption measurements. Figure S2 exhibits the nitrogen adsorption-desorption isotherms of ZIF-8 and nPANI@nZIF-8 samples at 77.4 K.

Pure samples of nZIF-8 indicate that at low pressures $\left(P / P_{0}\right.$ $<0.03$ ), there was a large increase in the adsorbed $N_{2}$ volume, indicating the presence of micropores. A second increase can be observed at higher pressures $\left(P / P_{0}>0.09\right)$, which is characteristic of meso- and macropores. The surface area value, calculated using the Brunauer-Emmett-Teller (BET) equation, and the total pore volume were $1658.49 \mathrm{~m}^{2} \mathrm{~g}^{-1}$ and 1.17 $\mathrm{cm}^{3} \mathrm{~g}^{-1}$, respectively, close to the values reported in the literature for ZIF-8. ${ }^{41,42}$

The isotherm of nPANI@nZIF-8, synthetized with $50 \mathrm{v} / \mathrm{v} \%$ of the PANI solution, did not show a significant amount of adsorbed nitrogen, and its surface area could not be calculated, suggesting the obstruction of the pores of nZIF-8 after interaction with nPANI.

In the analysis of transmission electron microscopy (TEM), the nanomaterial size was approximately $400 \mathrm{~nm}$ (see Figure S3). It can be assumed that there was an aggregation of the nanoparticles of ZIF-8 and coating of PANI on these agglomerates, indicating the excessive amount of nPANI.

Lower values were then chosen for the PANI nanoparticle solution $(1,5$, and $10 \mathrm{v} / \mathrm{v} \%)$ for each $100 \mathrm{~mL}$ of the total volume, and the nanomaterials were synthesized. After this, the synthesis was performed again with the analysis of pore volume and surface area (BET).

The nPANI@nZIF-8 nanomaterials showed type I isotherms, suggesting that the modification of nZIF-8 with nPANI occurred mainly in the mesopores and macropores (Figure 1). This hypothesis can be confirmed by the micropore volume values of these materials, which did not undergo significant changes after interaction with nPANI, whereas the volume of meso- and macropores decreased dramatically. The obstruc- 


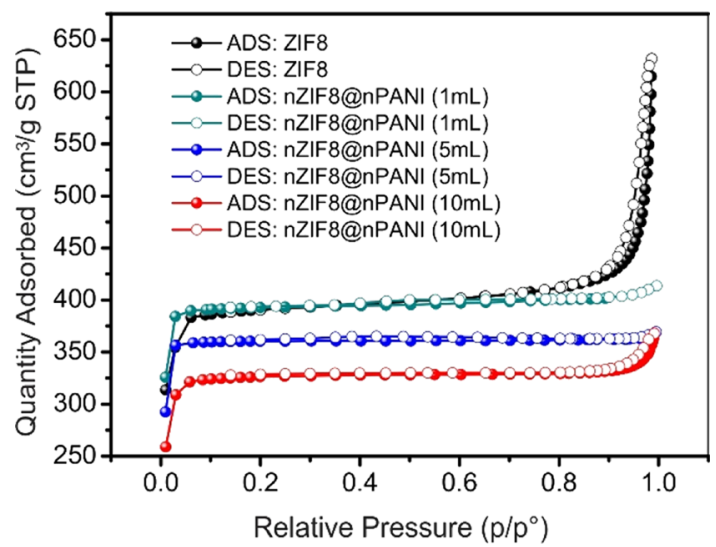

Figure 1. Nitrogen adsorption-desorption isotherms of nZIF-8 (black) and nPANI@nZIF-8 with $1 \mathrm{~mL}$ of nPANI (green), $5 \mathrm{~mL}$ of nPANI (blue), and $10 \mathrm{~mL}$ of nPANI (red) at $-196^{\circ} \mathrm{C}$.

tion of meso- and macropores resulted in an increase in the microporosity of the materials modified with nPANI. The microporosity of nZIF- 8 was $48.7 \%$; in the ZIFs modified with PANI, the values varied from 87.3 to $96.5 \%$ (Table 1). Thus, functionalization occurred mainly in the larger pores (mesoand macropores) because the diffusion of large molecules in these pores can occur more easily than in the smaller ones (micropores).

For a greater chemotherapeutic and photothermal effect, sufficient porosity on the carrier material is necessary, as well as boosted hyperthermia of the photothermal agent. Given this, we chose to use $5 \mathrm{~mL}\left(0.5 \mathrm{mg} \mathrm{mL}^{-1}\right)$ of the volume of PANI nanoparticles in the synthesis of the nPANI@nZIF-8 material in this study.

Similar results for the IR analysis of nZIF-8, the $\mathrm{N}-\mathrm{H}$ stretch band at $3135 \mathrm{~cm}^{-1}$, and the $\mathrm{C}-\mathrm{H}$ stretches of the methyl groups at $2929 \mathrm{~cm}^{-1}(\mathrm{C}-\mathrm{H}$ aliphatic imidazole $)$ and $1307 \mathrm{~cm}^{-1}$ are reported in the literature. ${ }^{43}$ The peak corresponding to the $\mathrm{C}-\mathrm{N}$ and $\mathrm{C}=\mathrm{N}$ bonds are located at 1457, 1423, and $1145 \mathrm{~cm}^{-1}$, displaced because of the coordination with the metal center. The absorption band at $421 \mathrm{~cm}^{-1}$ is associated with the $\mathrm{Zn}-\mathrm{N}$ stretch mode. An overlap occurs with the stretches and bands of the PANI nanoparticles. ${ }^{40}$ The peaks at about 1594 and $1504 \mathrm{~cm}^{-1}$ represent the quinoid and benzenoid rings present in nPANI. The peaks at 1300 and $1100 \mathrm{~cm}^{-1}$ are related to the $\mathrm{C}-\mathrm{N}$ and $\mathrm{C}=\mathrm{N}$ stretching modes, respectively, increasing the peak intensity in this region, as shown in Figure 2.

The TEM images confirmed that nPANI modified the external surface of nZIF-8 (Figure $3 \mathrm{~b}$ ). This modification could be due to the electrostatic attraction and chelation mechanism, between the basic sites of PANI (amine and imine nitrogen along the polymer backbone) and the metal cation

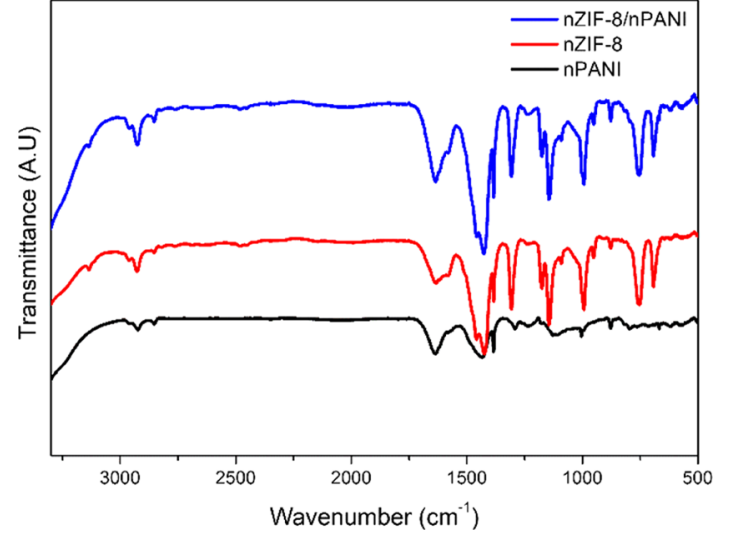

Figure 2. Overlapping IR spectra of nPANI, ZIF-8, and nPANI@ nZIF-8.

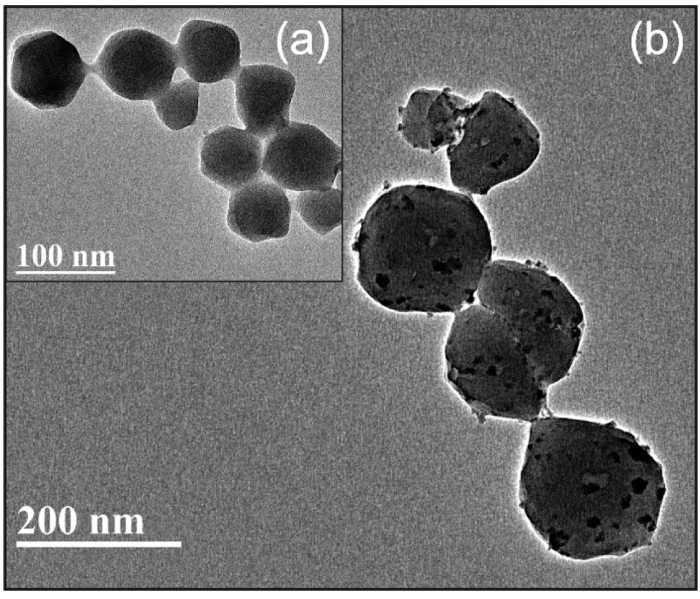

Figure 3. TEM analysis of pure nZIF-8 (a) and synthesized nPANI@ nZIF-8 ( $5 \mathrm{v} / \mathrm{v} \%$ of the nPANI solution) (b).

$\left(\mathrm{Zn}^{2+}\right) .{ }^{44}$ When synthesized with nPANI, the color of nZIF-8 turned from white to violet. This color is due to the presence of nPANI at its highest oxidation state. ${ }^{45}$ The TEM image of pure nZIF- 8 is also shown for comparison (Figure $3 a$ ). The average particle size of nZIF-8 was approximately $80 \mathrm{~nm}$. After contact with nPANI, the size of nPANI@nZIF-8 increased to approximately $200 \mathrm{~nm}$.

The stability and thermal decomposition of the samples were evaluated by thermogravimetric analysis before and after the decoration process with PANI (Figure 4a,b, respectively). The thermoanalytical profile of nZIF-8 displays a single step, which can be interpreted as the loss of the organic ligand, imidazolate, between the temperature ranges of $350-650{ }^{\circ} \mathrm{C}$. The missing $\mathrm{C}$ is combined with zinc to form $\mathrm{ZnC}$, generating a residual mass, after loss of the ligand, which corresponds to

Table 1. Textural Properties of nZIF-8 and nPANI@nZIF-8

\begin{tabular}{|c|c|c|c|c|c|}
\hline sample & $S_{\mathrm{BET}}^{a}\left(\mathrm{~m}^{2} \mathrm{~g}^{-1}\right)$ & $V_{\text {tot }}^{b}\left(\mathrm{~cm}^{3} \mathrm{~g}^{-1}\right)$ & $V_{\text {micro }}{ }^{c}\left(\mathrm{~cm}^{3} \mathrm{~g}^{-1}\right)$ & $V_{\text {meso }}{ }^{d}\left(\mathrm{~cm}^{3} \mathrm{~g}^{-1}\right)$ & microporous $^{e}(\%)$ \\
\hline nZIF-8 & 1658.49 & 1.17 & 0.60 & 0.57 & 48.7 \\
\hline nPANI@nZIF-8 (1 mL nPANI) & 1536.59 & 0.63 & 0.59 & 0.04 & 93.6 \\
\hline nPANI@nZIF-8 (5 mL nPANI) & 1418.86 & 0.57 & 0.55 & 0.02 & 96.5 \\
\hline nPANI@nZIF-8 (10 mL nPANI) & 1285.74 & 0.55 & 0.48 & 0.07 & 87.3 \\
\hline
\end{tabular}

${ }^{a} S_{\text {BET }}$ BET surface area. ${ }^{b}$ Total pore volume obtained by the sum of the volumes of micro- and mesopores. ${ }^{c}$ Volume of micropores obtained by $t$ plot method. ${ }^{d}$ Volume of mesopores obtained by the Barrett-Joyner-Halenda method. ${ }^{e}$ Microporosity obtained through the total volumes of pores and micropores. 

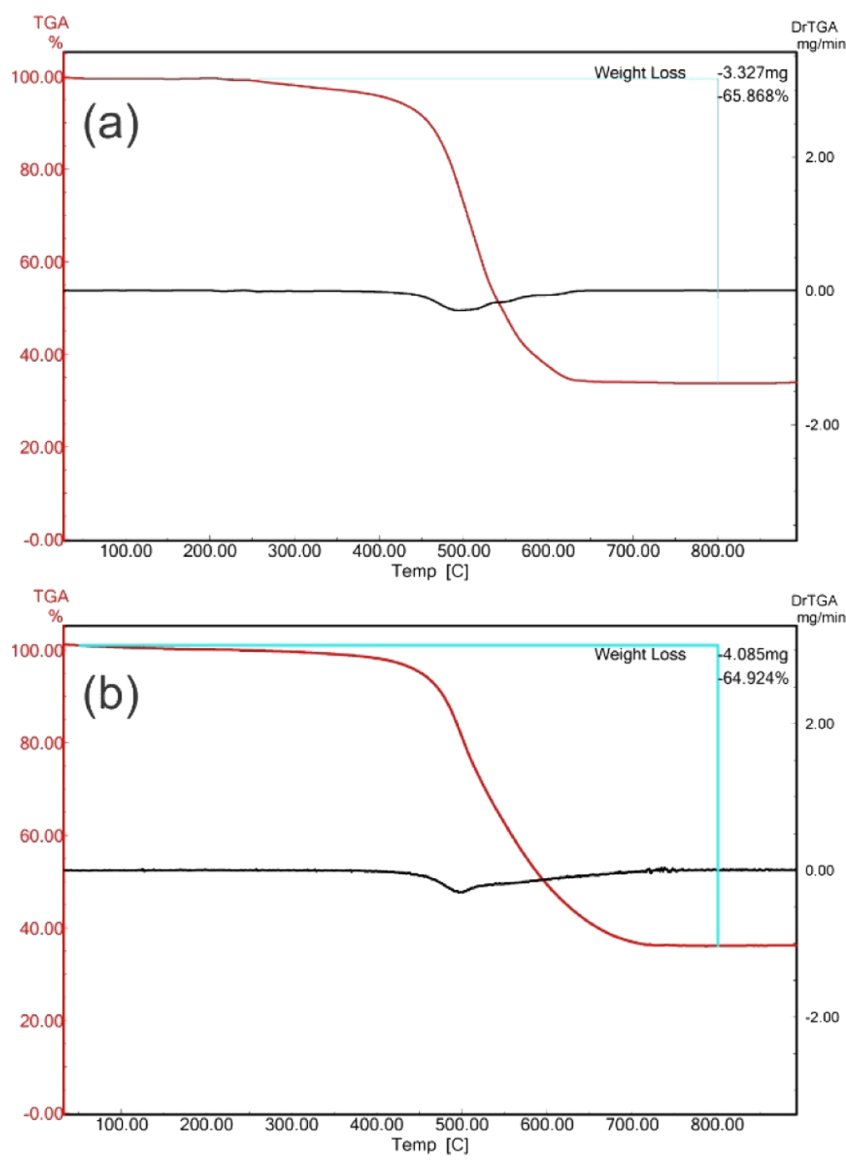

Figure 4. TGA of nZIF-8 (a) and nPANI@nZIF-8 (b).

$33.6 \%$ of the molecular mass of ZIF-8.nPANI@nZIF-8 had the same thermoanalytical profile as pure nZIF- 8 , but with a change in the temperature range in the loss of the organic ligand, imidazolate, from 350 to $750{ }^{\circ} \mathrm{C}$, approximately. This greater stability of the material could be due to the presence of PANI nanoparticles.

2.2. Loading and Release of the 5-FU Drug. To achieve a greater therapeutic efficacy, the 5-FU drug was selected as an antitumor model because of its small size, as well as its extensive use in the treatment of colorectal, breast, head, and neck cancers. ${ }^{46} \mathrm{UV}$-vis absorption spectroscopy was used to determine the effective storage capacity of 5-FU in nPANI@ nZIF-8.

Because of the presence of the PANI nanoparticles, there was a drastic decrease in the volume of the mesopores of the nZIF-8 metallographic network. Therefore, loading of the 5FU drug occurred preferentially in the micropores. The adsorption-desorption isotherms of nPANI@nZIF-8 before and after loading the 5-FU drug are shown in Figure 5 and pointed a decrease in the surface area from 1418.86 to 876.29 $\mathrm{m}^{2} \mathrm{~g}^{-1}$ and pore volume from 0.57 to $0.39 \mathrm{~cm}^{3} \mathrm{~g}^{-1}$ after loading the drug.

Figure 6 shows the UV-vis absorption spectra of the original 5-FU aqueous solution $(0 \mathrm{~h})$ and the residual 5-FU content in the supernatant after the interaction with nPANI@ nZIF-8 (48 h). The aliquots were analyzed by UV-vis, and the 5-FU drug was quantified using the calibration curve ( $Y=$ 15.52952, $\left.X=0.09699, R^{2}=0.9967\right)$.

The adsorption process was effective at $20.22 \%$. The drug encapsulation efficiency (DEE), calculated by the decom-

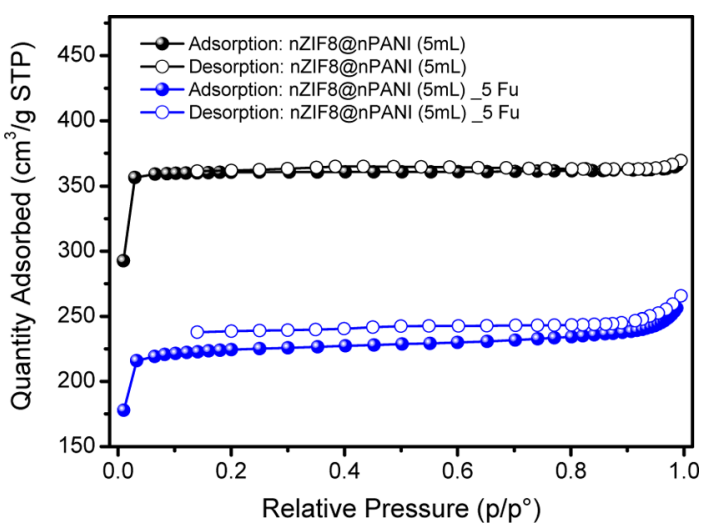

Figure 5. $\mathrm{N}_{2}$ adsorption-desorption isotherms of ZIF-8 before and after loading the 5-FU drug.

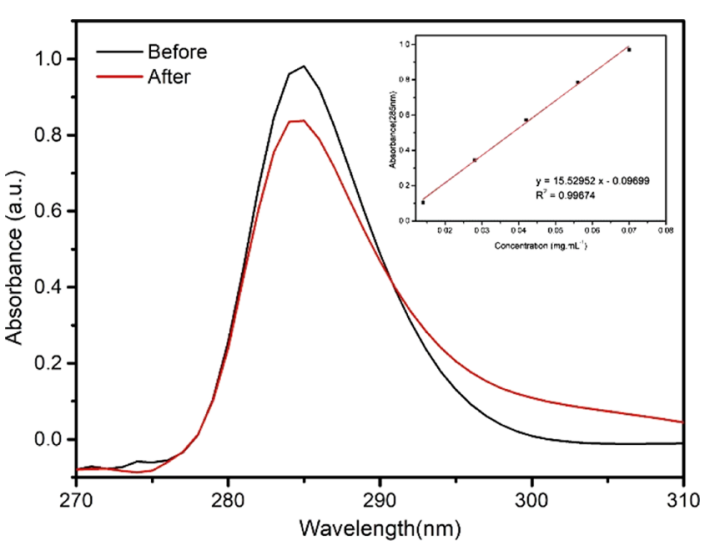

Figure 6. Absorption spectrum of the 5-FU drug before and after contact with nPANI@nZIF-8 (48 h). In the inset, the 5-FU calibration curve at $285 \mathrm{~nm}$ is shown.

position of $1 \mathrm{mg}$ of nPANI@nZIF-8/5-FU, approximately (18.17\%), confirmed the amount of drug loaded in the adsorption process. These results are compared to the weight of the total drug injected. This small variation suggests that the adsorptive process is not completely homogeneous over the mass of nPANI@nZIF-8/5-FU.

The drug loading content (DLC) shows a load of $0.3 \mathrm{mg}$ of 5-FU mg ${ }^{-1}$ nPANI@nZIF-8 according to the adsorption kinetic curve (Figure S4).

To investigate the behavior of 5-FU, the cumulative release profiles in the buffer solutions with $\mathrm{pH}$ 7.2, $\mathrm{pH}$ 5.2, and $\mathrm{pH} 5.2$ under NIR laser irradiation were tested.

Approximately 58 and $68 \%$ of the encapsulated 5-FU were released at $\mathrm{pH} 7.2$ and $\mathrm{pH}$ 5.2, respectively, after $6 \mathrm{~h}$, as shown in Figure 7.

The initial rapid drug release is due by the quick release of 5FU molecules adsorbed onto the surface of nPANI@nZIF-8/5FU. The other 5-FU molecules entrapped in the pores and cavities of nPANI@nZIF-8/5-FU are released slowly. This has also been observed in other papers reported in the literature using the MOF ZIF-8 as the carrier of the 5-FU drug. ${ }^{46,47}$

The release of 5-FU from nPANI@nZIF-8 has presented the best answer at a lower $\mathrm{pH}$. This result is associated with the partial or total decomposition of nZIF-8 as has been reported previously. ${ }^{4,35,36,46}$ These release behaviors make nPANI@ nZIF-8/5-FU a potential $\mathrm{pH}$-responsive drug delivery system for cancer therapy. In general, tumor cells present a higher 


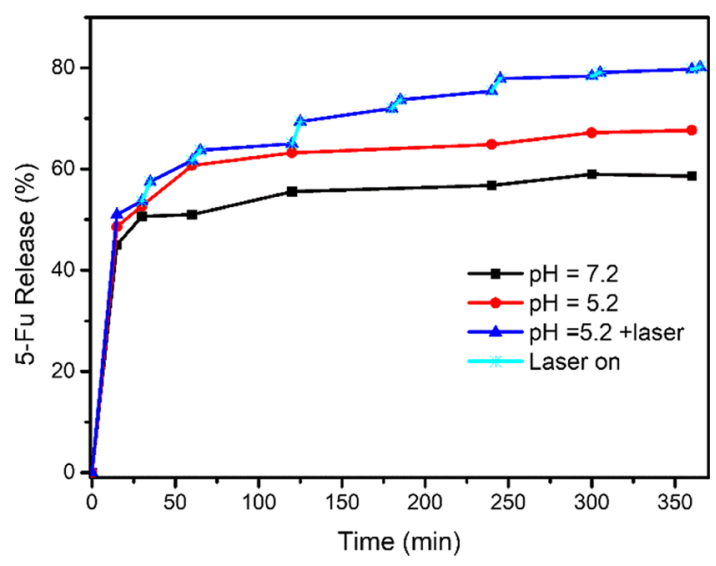

Figure 7.5-FU release profiles from system-loaded nPANI@nZIF-8@ 5-FU in buffer solutions with $\mathrm{pH} 7.2, \mathrm{pH} 5.2$, and $\mathrm{pH} 5.2$ under NIR laser ON/OFF irradiation $\left(980 \mathrm{~nm}, 0.8 \mathrm{~W} \mathrm{~cm}^{-2}\right)$.

acidic condition ${ }^{47}(\mathrm{pH} 4.5-6.0)$; therefore, this is the place where there will be a greater delivery of the drug.

Under the action of the NIR laser, the cumulative release profile of the 5-FU drug in the buffer solution at $\mathrm{pH} 5.2$ reached $80 \%$. This increase shows that the NIR light significantly enhanced the release of the drug. Temperature is an important factor in the control of the diffusion rate of drug molecules. ${ }^{16}$ Absorption of the NIR light by PANI causes local hyperthermia by aiding the diffusion of the drug molecules contained by the polymer intonPANI@nZIF-8/5FU.

Powder XRD was performed to evaluate the possible alterations in the ZIF-8 structure. The XRD analysis of nPANI@nZIF-8 showed no change compared to the XRD of the MOF ZIF-8 (COD \# 4118891). The XRD spectra showed intense, narrow, and well-defined peaks, indicating the crystallinity of nZIF-8, as reported in the literature. ${ }^{43,48}$ Thus, there was no change in the crystallographic phases of the network nZIF-8 because of the presence of PANI nanoparticles (Figure 8), indicating a low nPANI concentration and a lower XRD signal intensity compared with nZIF8.

The incorporation of the 5-FU drug maintains the crystallinity of the network, as shown in Figure 8, with a diffractogram illustrating the characteristic peaks of nZIF-8. It

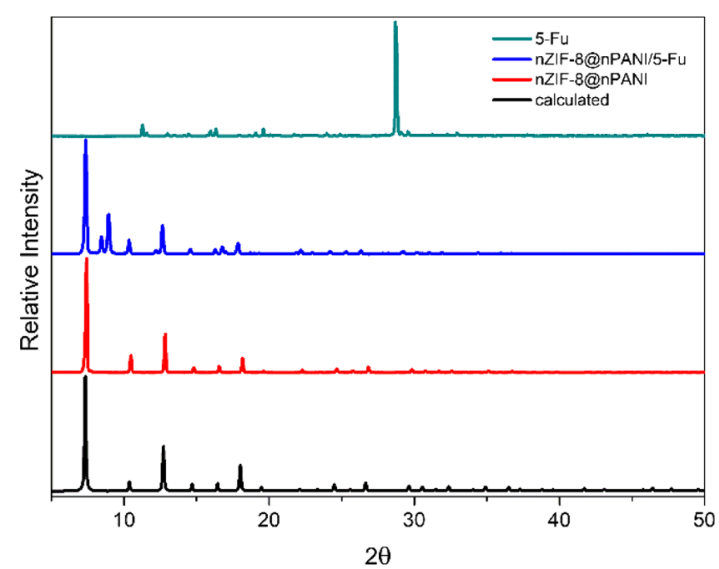

Figure 8. Overlapping diffractograms of ZIF-8 (theoric), nZIF-8@ nPANI, nPANI@nZIF-8/5-FU, and 5-FU. is suggested that the disappearance of the 5-FU peak in the XRD analysis is due to the dissolution of the 5-FU crystals in methanol and subsequent "molecular" loading, of 5-FU, in the ZIF-8 network. Similar results have been described in the literature. $\mathrm{Sun}^{46}$ and $\mathrm{Gao}^{47}$ reported the preservation of the crystallinity of the ZIF- 8 network in the process of incorporation of the 5-FU drug.

The IR spectra indicates the incorporation of the drug molecule after loading 5-FU in nPANI@nZIF-8. New peaks were observed, which linked the drug ${ }^{49}$ (Figure 9). The peak

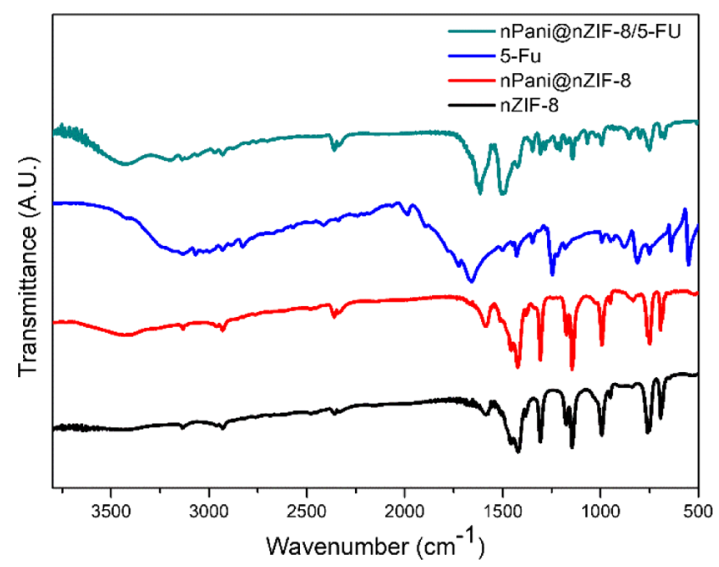

Figure 9. Overlapping IR spectra of nZIF-8, nPANI@nZIF-8, 5-FU, and nPANI@nZIF-8/5-FU.

$1275 \mathrm{~cm}^{-1}$ belongs to the stretch band $\mathrm{C}-\mathrm{F}$, the peak 1650 $\mathrm{cm}^{-1}$ belongs to the carbonyl stretch of 5-FU $(\mathrm{C}=\mathrm{O})$, and the peak $3000-3500 \mathrm{~cm}^{-1}$ belongs to the $-\mathrm{NH}$ band of 5-FU.

2.3. Photothermal Effect of nPANI@nZIF-8. The strength of the NIR uptake of the PANI nanoparticles described in the literature motivated us to investigate their application as photothermic ablation agents, in a multifunctional nanomaterial together, with the porous network nZIF-8.

In the absorption spectrum, only aqueous solutions of nPANI and nPANI@nZIF-8 showed the NIR absorption band in the range $700-1100 \mathrm{~nm}$. The pure nZIF- 8 produced an absorption band at $214 \mathrm{~nm}$ (Figure 10). Therefore, the photothermal effect was attributed in the presence of the PANI nanoparticles. This proves the potential use of nPANI@nZIF-8 as photothermal ablation agents in cancerous cells.

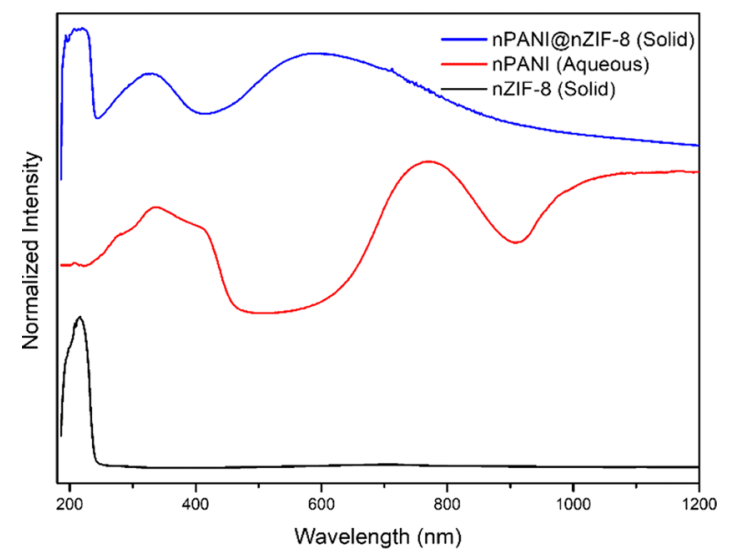

Figure 10. UV-vis spectra of nZIF-8 (solid), nPANI (aqueous), and nPANI@nZIF-8 (solid). 
In an aqueous solution, the nPANI@nZIF-8 absorption bands displaced to the right, increasing the absorption in the NIR region as shown in Figure 11. The changes in the values of the absorption bands suggest the nPANI interaction with nZIF-8.

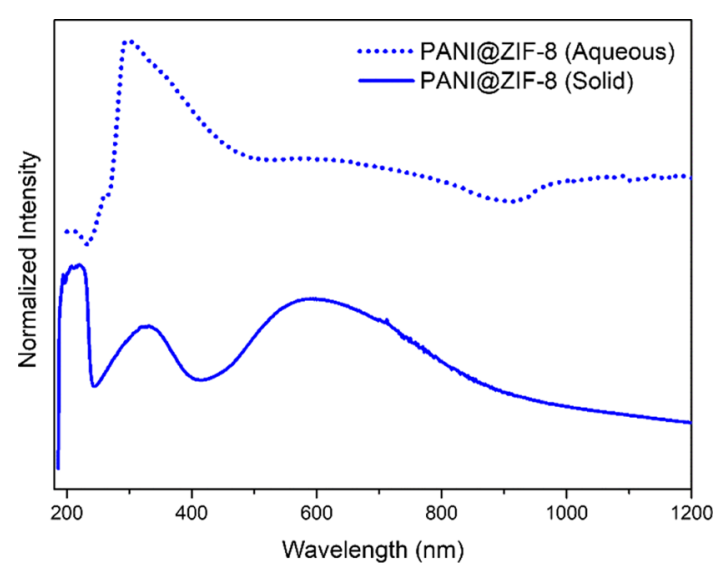

Figure 11. UV-vis spectra of nPANI@nZIF-8, solid and in suspension aqueous.

To analyze the photothermal profile of nPANI@nZIF-8, 200 $\mu \mathrm{L}$ of the solution of this nanomaterial in different concentrations $\left(0.0625,0.125,0.25,0.5\right.$, and $1 \mathrm{mg} \mathrm{mL}^{-1}$ ) was irradiated under the NIR laser $\left(980 \mathrm{~nm}, 0.8 \mathrm{~W} \mathrm{~cm}^{-2}\right)$ for 5 min (Figure 12), with pure water selected as the control. The

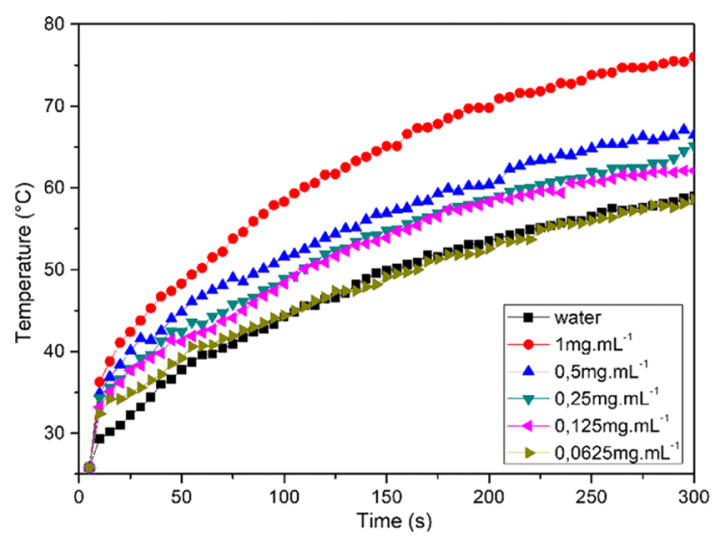

Figure 12. Photothermal effects of a solution of nPANI@nZIF-8 using NIR irradiation $(\lambda=980 \mathrm{~nm})$ for $5 \mathrm{~min}$, in the volume of 200 $\mu \mathrm{L}$ with different concentrations: $0.0625,0.125,0.25,0.5$, and $1 \mathrm{mg}$ $\mathrm{mL}^{-1}$ and in pure water at $0.8 \mathrm{~W} \mathrm{~cm}^{-2}$.

local maximum temperatures could be measured using an IR thermal camera. The temperature rose with each increased concentration of nPANI@nZIF-8 and with the increase of the irradiation time. Furthermore, we evaluated the photothermal conversion efficiency $(\eta)$ of nPANI@nZIF-8 used in eqs 1 and 2 described in the Experimental Procedure section using the same parameters, laser power $\left(0.8 \mathrm{~W} \mathrm{~cm}^{-2}\right)$ and concentration $(250 \mu \mathrm{g} / \mathrm{mL})$, used in the cell viability assay. The value obtained was $\eta=41 \%$. This result indicates that nPANI@ nZIF-8 shows a high potential to be used as the photothermal agent at the PPT.

In the cell viability test, under the action of the laser, we could notice that the power of $800 \mathrm{~mW}$ allows a cellular viability of $98.62 \%$. Therefore, irradiation of the cell culture medium for $5 \mathrm{~min}$ does not cause cell death at this potency, suggesting that the average temperature in the region is lower than the maximum point temperature.

The use of $980 \mathrm{~nm}$ laser has some advantages compared to lasers with smaller wavelengths. For example, the conservative limit of $980 \mathrm{~nm}$ laser intensity set for human skin exposure is $\sim 0.726 \mathrm{~W} \mathrm{~cm}{ }^{-2}$, which is more than twice that $(\sim 0.33 \mathrm{~W}$ $\mathrm{cm}^{-2}$ ) of the $808 \mathrm{~nm}$ laser, based on the American National Standard for the Safe Use of Lasers. Thus, the depth of irradiation of the laser at $980 \mathrm{~nm}$ can be several centimeters in biological tissues.

We used a power of $0.8 \mathrm{~W} \mathrm{~cm} \mathrm{~cm}^{-2}$, which is the same power used in the test with in vitro cancer cells, less than that reported in other studies. ${ }^{14}$

2.4. In Vitro Cytotoxicity. The effect of NIR laser and the potential cytotoxicity of synthesized nPANI@nZIF-8 against the breast cancer line MCF7 cells were examined. An experiment which related to the effect of NIR laser on cell viability under different power densities was further studied. Figure 13 shows that more than $93.32 \%$ of MCF7 cells

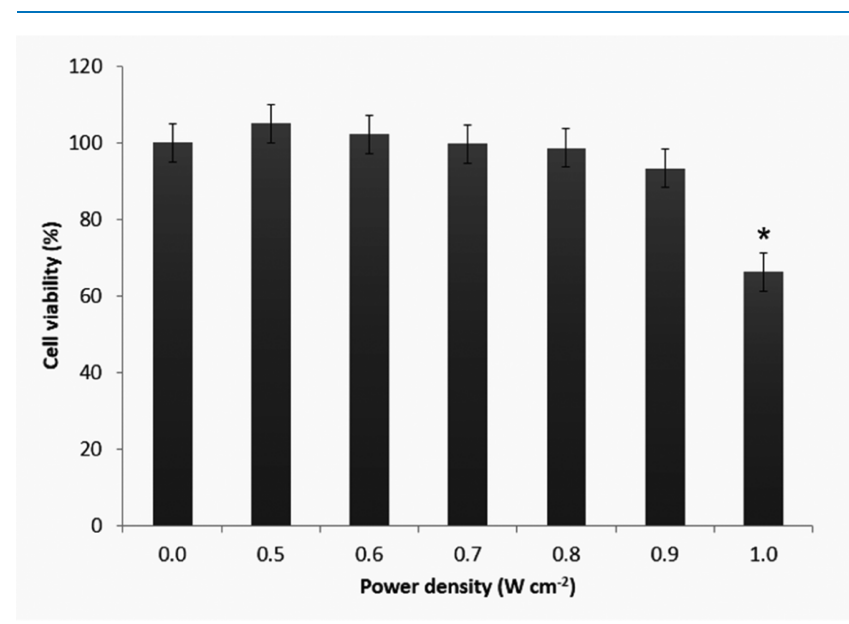

Figure 13. Effect of NIR laser $(980 \mathrm{~nm})$ on the cell viability of MCF7 cells.

survived after irradiation with the NIR laser at the power densities of $0.5,0.6,0.7,0.8$, and $0.9 \mathrm{~W} \mathrm{~cm}^{-2}$. When the power density of the NIR laser was increased to $1.0 \mathrm{~W} \mathrm{~cm}^{-2}$, however, the cell viability decreased to a $66.33 \%$ survival. This decrease of cell viability can be attributed to hyperthermia triggered by the NIR laser at the greater power density. Given these results, we selected a laser power density of $0.8 \mathrm{~W} \mathrm{~cm}^{-2}$ to be used in the following experiments considering that this density triggered a sufficient photothermal conversion effect for cancer PTT and was less cytotoxic for cells (98.62\%).

The MCF7 cells were treated with different concentrations $(0-1000 \mu \mathrm{g} / \mathrm{mL})$ of nPANI@nZIF-8 for $72 \mathrm{~h}$, and then an 3(4,5-dimethylthiazol-2-yl)-2,5-diphenyl tetrazolium bromide (MTT) assay was used to measure the mitochondrial activity in the viable cells. Figure 14 shows the concentrations between 62.5 and $250 \mu \mathrm{g} / \mathrm{mL}$, demonstrating the percentages of the viable cells over $80 \%$, suggesting no appreciable cytotoxicity of nPANI@nZIF-8 up to $250 \mu \mathrm{g} / \mathrm{mL}$. However, concentrations above $500 \mu \mathrm{g} / \mathrm{mL}$ decreased the cell viability. Therefore, the chemo-PTT assay in vitro was performed in the concentrations of 125 and $250 \mu \mathrm{g} / \mathrm{mL}$.

The stability of nPANI@nZIF-8 exhibited an excellent homogeneity and stability in the water and culture medium for 


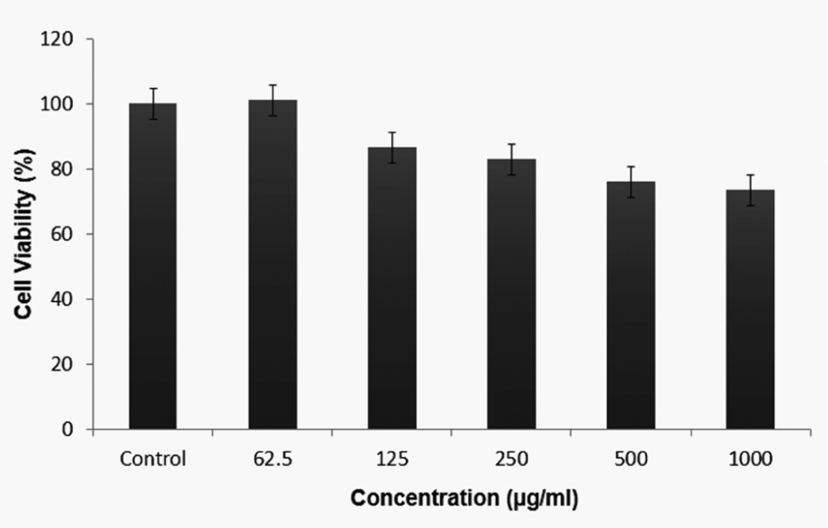

Figure 14. Cell viability of MCF7 cells after $72 \mathrm{~h}$ of incubation with nPANI@nZIF-8 at different concentrations as measured using an MTT assay. The values are shown as mean \pm standard deviation (SD).

up to $8 \mathrm{~h}$ (Figure 15) and showed the stability for in vitro biomedical applications.

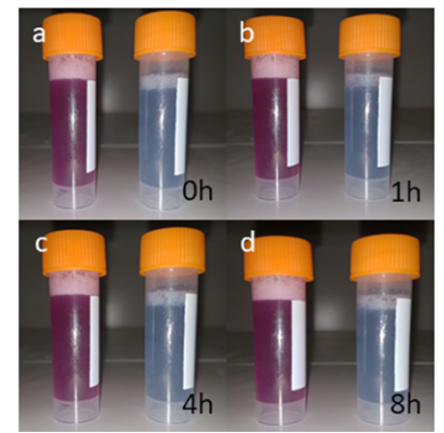

Figure 15. Images of the nPANI@nZIF-8 $(500 \mu \mathrm{g} / \mathrm{mL})$ system in the culture medium (red) and pure water (green) at times 0 (a), 1 (b), 4 (c), and $8 \mathrm{~h}(\mathrm{~d})$.

2.5. Chemo-PTT in Vitro of nPANI@nZIF-8/5-FU Nanoparticles. To investigate the chemo-photothermal in vitro effects of the nPANI@nZIF-8/5-FU nanoparticles on therapeutic efficiency, MCF7 cells were treated for $72 \mathrm{~h}$ with the free 5-FU $(0.0625 \mu \mathrm{g} / \mathrm{mL})$, nPANI@nZIF-8 (125 and 250 $\mu \mathrm{g} / \mathrm{mL}$ ), and nPANI@nZIF-8/5-FU at the same concentrations. This procedure was followed by NIR irradiation for 5 $\min$ at $0.8 \mathrm{~W} \mathrm{~cm}{ }^{-2}$. As shown in Figure 16, in the concentrations studied, nPANI@nZIF-8 kept the cell viability above $80 \%$. In contrast, the cytotoxicity of the 5 -FU-loaded nPANI@nZIF-8 was significant, reducing the viability to 70.32 and $58.98 \%$ at the concentrations of 125 and $250 \mu \mathrm{g} / \mathrm{mL}$, respectively.

When NIR irradiation was applied to treat the MCF7 cells after incubation with the nPANI@nZIF-8/5-FU nanoparticles, the cell viability decreased significantly (approximately 50 and $33 \%$ at the concentrations of 125 and $250 \mu \mathrm{g} / \mathrm{mL}$, respectively).

The nanomaterials carried with 5-FU were shown to be more efficient than the free drug.

According to Tian et al, the use of functionalized nZIF-8, with photoabsorbers, located in tumors, resulted in the irreversible cell damage and subsequent destruction of the tumor because of the conversion of the NIR-irradiated energy

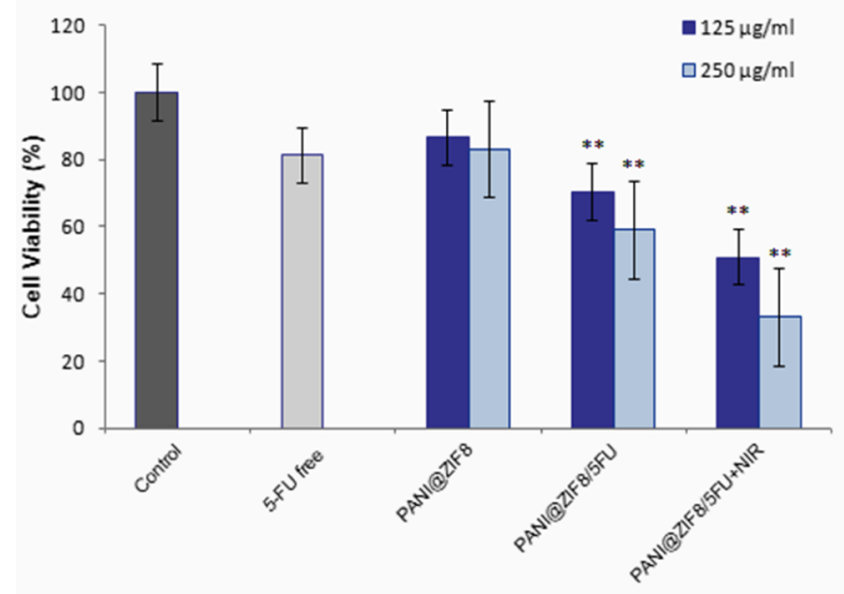

Figure 16. In vitro cytotoxicity of free 5-FU, nPANI@nZIF-8, nPANI@nZIF-8/5-FU, and nPANI@nZIF-8/5-FU nanoparticles in different concentrations $\left(0.25\right.$ and $\left.0.125 \mathrm{mg} \mathrm{mL}^{-1}\right)$ on MCF7 cells after $72 \mathrm{~h}$ of incubation. The values are shown as mean $\pm \mathrm{SD} ; n=4$, $* P<0.05, * * P<0.01$.

into heat. ${ }^{4}$ This contributes to its use as a multifunctional platform and thus increases the therapeutic efficacy. Therefore, it can be concluded that nPANI@nZIF-8/5-FU shows the potential as a new chemo-photothermal platform for cancer therapy.

\section{CONCLUSIONS}

The multifunctional system has been developed and used successfully as a new platform for cancer therapy. The development of nPANI@nZIF-8 was achieved quickly and effectively, validated by the characterization reported, and used as a carrier of the 5-FU drug in the nZIF-8 and the nPANIdecorated networks as a photothermal agent. The drug release resulted in an improved $\mathrm{pH}$, and under NIR laser irradiation, reaching $80 \%$. The cellular viability of the MCF7 cells decreased significantly, approximately $33 \%$, after incubation with nPANI@nZIF-8/5-FU and laser NIR action at $0.8 \mathrm{~W}$ $\mathrm{cm}^{-2}$ in $5 \mathrm{~min}$. Therefore, it can be concluded that nPANI@ nZIF-8/5-FU has an excellent chemo-photothermal effect against breast cancer cells and thus shows a high potential for PTT.

\section{EXPERIMENTAL PROCEDURE}

4.1. Materials and Methods. All the reagents used here were analytically pure unless stated otherwise. The solutions were prepared in water purified by reverse osmosis and then deionized $(18 \mathrm{M} \Omega \mathrm{cm})$ with a Milli-Q gradient Millipak 40 . The $\mathrm{pH}$ of the solutions was measured with the aid of a Quimis Q400MT $\mathrm{pH}$ meter.

Aniline (Vetec), $\mathrm{C}_{6} \mathrm{H}_{5} \mathrm{NH}_{2}$, high-performance liquid chromatography grade supplied by Aldrich, was distilled under vacuum at a temperature of $60^{\circ} \mathrm{C}$ before being used.

Other chemicals employed were $\mathrm{HCl}$ (Vetec) to adjust the $\mathrm{pH}$, oxidant $\left(\mathrm{NH}_{4}\right)_{2} \mathrm{~S}_{2} \mathrm{O}_{8}$ (Aldrich), surfactant $\mathrm{C}_{12} \mathrm{H}_{25} \mathrm{NaSO}_{4}$ (Merck), solvent methanol (Dinâmica), 2-methyl imidazole (Aldrich), $\mathrm{Zn}\left(\mathrm{NO}_{3}\right)_{2}$ (Aldrich), and drug 5-FU (Aldrich).

The hyperthermia study was performed with the aid of a laser (laser diode), serial number, 1002, DMC LTD instrument equipped with an excitation diode of $980 \pm 10 \mathrm{~nm}$, 
optical fiber UV/SR, and $600 \mu \mathrm{m}$. The thermographic images were obtained by a FLIR model E4 Thermovisor.

4.2. Synthesis of nPANI@nZIF-8. To obtain a solution of nPANI, $83 \mu \mathrm{L}$ of the aniline monomer was used, $0.042 \mathrm{~g}$ of oxidant $\left(\mathrm{NH}_{4}\right)_{2} \mathrm{~S}_{2} \mathrm{O}_{8}$ and $1.329 \mathrm{~g}$ of the surfactant that had been already used for the synthesis of PANI nanoparticles in the micellar solution $^{50}$ and sodium dodecyl sulfate $\mathrm{C}_{12} \mathrm{H}_{25} \mathrm{NaSO}_{4}$. These reagents were dissolved in the acid medium, $50 \mathrm{~mL}$ of aqueous $0.1 \mathrm{M} \mathrm{HCl}$. The reagents were left under stirring for $24 \mathrm{~h}$.

The synthesis of decorated nZIF-8 was adapted from the methodology of Guang Lu et al. ${ }^{37}$ Volumes $(50,10,5$, and 1 $\mathrm{mL}$ ) of the previously prepared nPANI solution were added and with enough methanol to make a $100 \mathrm{~mL}$ final solution. Then, these volumes were divided into two containers to dissolve the reagents 2 -methyl imidazole $(810 \mathrm{mg})$ and zinc nitrate $(742 \mathrm{mg})$. Then, the solution containing the ligand was added to the beaker containing the metal ion and allowed to stir for $15 \mathrm{~min}$. After that time, it was left for $24 \mathrm{~h}$ to rest. After the synthesis, the solution was centrifuged, and the final product was washed with 1:1 methanol and water and suspended three times with the aid of a Vortex stirrer. The final solid was dried in a desiccator coupled to a vacuum pump.

4.3. Characterization of nPANI@nZIF-8 and nPANI@ nZIF-8/5-FU. Diffractograms were recorded at room temperature in the range of $5^{\circ}-50^{\circ}$ in a Rigaku $2400 \mathrm{D} / \mathrm{Max}$ X-ray diffractometer with $\mathrm{Cu} \mathrm{K} \alpha(0.15 \mathrm{~nm})$. Vibrational spectra were obtained by Fourier transform infrared spectroscopy (FTIR) analysis, in a VERTEX 70/70v Bruker FTIR spectrometer, performed on $\mathrm{KBr}$ pellets in the range of $4000-400 \mathrm{~cm}^{-1}$. The TGAs were performed in a Shimadzu DTG-60H analyzer in a $\mathrm{N}_{2}$ atmosphere from room temperature to $800{ }^{\circ} \mathrm{C}\left(10{ }^{\circ} \mathrm{C} /\right.$ $\left.\mathrm{min}^{-1}\right)$. The pore volume and the surface area measurements were performed in a Micromeritics ASAP 2010 apparatus. About $100 \mathrm{mg}$ of each sample was dried in an oven at $100{ }^{\circ} \mathrm{C}$ for $12 \mathrm{~h}$, before being placed in a quartz cuvette and attached to the physisorption apparatus. The sample was dried under vacuum at $100{ }^{\circ} \mathrm{C}$ for $5 \mathrm{~h}$. The BET surface area and the pore volume were obtained by $\mathrm{N}_{2}$ physisorption at $77.4 \mathrm{~K}$. A thermos-scientific Jeol JEM 2100 transmission electron microscope enabled us to acquire the high-resolution images for the nanometric compounds. The images were obtained using the microscope user interface (Fey Company) and TEM Imagine and Analysis software.

4.4. Photothermal Effect of nPANI@nZIF-8. The temperature elevation of nPANI@nZIF-8 was investigated in an aqueous solution under irradiation with a laser $\operatorname{NIR}(\lambda=$ $980 \mathrm{~nm})$.

A volume of $200 \mu \mathrm{L}$ of the aqueous solution of nPANI@ nZIF-8 in suspension, at different concentrations $(0,0.0625$, $0.125,0.25,0.5$, and $\left.1 \mathrm{mg} \mathrm{mL}^{-1}\right)$, was irradiated under $980 \mathrm{~nm}$ NIR laser at different power densities $\left(0.5\right.$ to $\left.1 \mathrm{~W} \mathrm{~cm}^{-2}\right)$ for 5 min. The temperature was monitored by heating maps that were recorded by a thermal imager (FLIR E4) every $5 \mathrm{~s}$ for a period of $5 \mathrm{~min}$.

4.5. Photothermal Conversion Efficiency $(\boldsymbol{\eta})$. The photothermal conversion efficiency was calculated using eq 1 , already reported in the literature. ${ }^{18,51}$ The temperature variation as a function of time was recorded under continuous irradiation of the $980 \mathrm{~nm}$ laser, with a power density of $0.8 \mathrm{~W}$ $\mathrm{cm}^{-2}$ in a nPANI@nZIF-8 solution $(250 \mu \mathrm{g} / \mathrm{mL})$ for $5 \mathrm{~min}$.

$$
\eta=\frac{h S\left(T_{\max }-T_{\text {vis }}\right)-Q_{0}}{I\left(1-1.10^{-A_{980}}\right)}
$$

where $h$ is the heat-transfer coefficient, $S$ is the container surface area, $T_{\max }$ is the equilibrium temperature of the nPANI@nZIF-8 system, $T_{\text {vis }}$ is the ambient temperature, $Q_{0}$ is associated with the heat generated only by the quartz cuvette and the solvent (water) under irradiation of the laser $(0.8 \mathrm{~W}$ $\left.\mathrm{cm}^{-2}\right), A_{980}$ is the absorption intensity of nPANI@ZEEIF-8 $\left(A_{980}=0.03\right)$, and $I$ is the incident laser power $0.8 \mathrm{~W} \mathrm{~cm}^{-2}$. The value of $h S$ was calculated from eq 2

$$
\tau=\frac{\sum m_{\mathrm{i}} \cdot C_{\mathrm{p}, \mathrm{i}}}{h S}
$$

where $\tau$ is the system time constant represented by the slope of the cooling line of sample (Figure 17), $m_{\mathrm{i}}$ is the mass of the

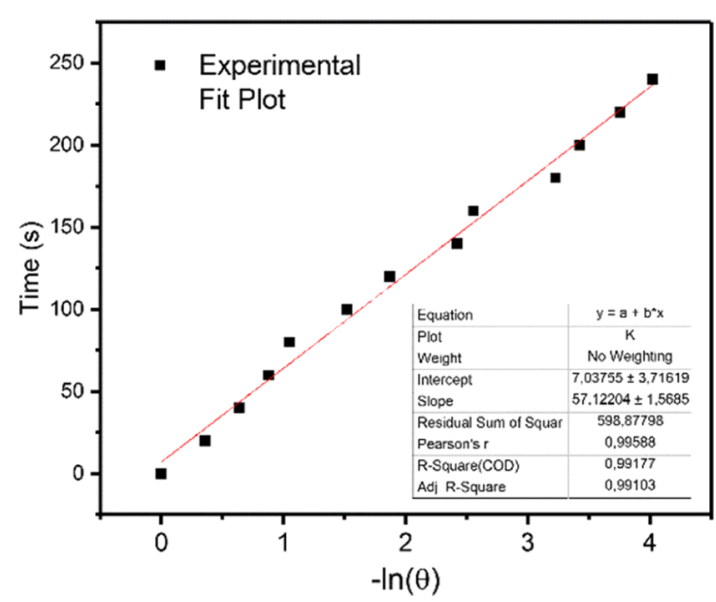

Figure 17. Cooling time vs negative natural logarithm of the driving force temperature.

cuvette $(1.62 \mathrm{~g})$ and mass of the water $(0.3 \mathrm{~g}), C_{\mathrm{p}, \mathrm{i}}$ is the calorific capacity of the cuvette $\left(0.89 \mathrm{~J} \mathrm{~g}^{-1} \mathrm{~K}^{-1}\right)$ and calorific capacity of water $\left(4.19 \mathrm{~J} \mathrm{~g}^{-1} \mathrm{~K}^{-1}\right)$.

4.6. Loaded 5-FU Drug in nPANI@nZIF-8/5-FU Nanoparticles. The incorporation of the 5-FU drug into nPANI@ nZIF-8 was performed by agitation for two days $(48 \mathrm{~h})$, according to the methodology adapted as proposed by Sun et al. $^{46}$

nPANI@nZIF-8 (40 mg) was dried and activated at $160{ }^{\circ} \mathrm{C}$ for $24 \mathrm{~h}$ in a vacuum oven and subsequently added to the solution of the drug previously prepared. The drug 5-FU (60 $\mathrm{mg}$ ) was dissolved by stirring and sonicated in $10 \mathrm{~mL}$ of methanol. Aliquots of the supernatant were collected at predefined times over $48 \mathrm{~h}$ and analyzed by UV-vis to obtain a kinetic adsorption curve (see Supporting Information S1 file). During the process, the 5-FU concentration was determined from the absorbance at $285 \mathrm{~nm}$ with the aid of an external calibration curve with standard solutions (0.01$0.07 \mathrm{mg} \mathrm{mL}^{-1}$ ).

To confirm the adsorption and the amount of the drug loaded,nPANI@nZIF-8/5-FU was completely decomposed with $0.35 \mu \mathrm{L}$ of $\mathrm{HCl}(2 \mathrm{M})$, diluted to $3 \mathrm{~mL}$ of phosphatebuffered solution (PBS), and analyzed by UV-vis. The 5-FU DLC \% of nPANI@nZIF-8/5-FU and the 5-FU DEE \% were calculated by the equations given below: ${ }^{52}$ 


$$
\begin{aligned}
& \operatorname{DLC}(\%)=\frac{\text { Weight of drug in nanocomposites }}{\text { Weight of nanocomposites taken }} \times 100 \\
& \operatorname{DEE}(\%)=\frac{\text { Weight of drug in nanocomposites }}{\text { Weight of total drug injected }} \times 100
\end{aligned}
$$

4.7. Drug Delivery and Studies under Stimulus Response. The drug delivery study was conducted over a period of 48 h. nPANI@nZIF-8/5-FU was resuspended in 0.5 $\mathrm{mL}$ of $0.1 \mathrm{M}$ PBS, $\mathrm{pH}=7.4$, sealed within a dialysis membrane $\left(M_{\mathrm{w}}\right.$ cut, $\left.3.5 \mathrm{kDa}\right)$, and placed in the release medium $(3 \mathrm{~mL}$ of $0.1 \mathrm{M}$ pure $\mathrm{PBS}$ ) under oscillation. At selected time intervals, $0.35 \mu \mathrm{L}$ of the buffer of the release medium (outside the dialysis bag) was collected in triplicate for UV-vis analysis and replaced with a fresh buffer solution. The released amount of 5-FU was determined using a 5-FU calibration curve.

The stimulus response tests for drug release were performed at $\mathrm{pH}=5.2$, also for $48 \mathrm{~h}$ and under the action of the NIR laser "on" ( $\left.\lambda=980 \mathrm{~nm}, 0.8 \mathrm{~W} \mathrm{~cm}^{-2}\right)$ at predetermined times (for 5 $\min )$, for $6 \mathrm{~h}$.

4.8. In Vitro Cytotoxicity. The in vitro cytotoxicity of nPANI@nZIF-8 was evaluated using an MTT assay. In this study, the breast cancer line MCF7 cells $\left(1 \times 10^{4}\right.$ cells per well) were seeded into the 96-well plates. Subsequently, the cells were cultured in the RPMI 1640 media, containing $10 \%$ fetal bovine serum, and incubated under a humidified atmosphere for $24 \mathrm{~h}\left(37{ }^{\circ} \mathrm{C}, 5 \% \mathrm{CO}_{2}\right)$. To study the effect of NIR laser on the cell viability, MCF7 cells were irradiated with the NIR laser under different power densities for $5 \mathrm{~min}$.

Another sample was used to study the cytotoxicity of nPANI@nZIF-8. MCF7 cells $\left(1 \times 10^{4}\right.$ cells per well $)$ were also seeded into the 96-well plates and subsequently incubated according to the method described above. After that, the cells were respectively treated with nPANI@nZIF-8 in different concentrations $(0-1000 \mu \mathrm{g} / \mathrm{mL})$ for $72 \mathrm{~h}$. Then, all of the supernatants were removed, and the cells on the 96-well plate were further treated with $20 \mu \mathrm{L}$ of MTT $\left(0.5 \mathrm{mg} \mathrm{mL}^{-1}\right)$ and 1 $\mu \mathrm{L}$ of MTT in the RPMI 1640 cell culture medium for $3 \mathrm{~h}$. Subsequently, the MTT medium was carefully removed, and $100 \mu \mathrm{L}$ of dimethyl sulfoxide was added to each well and measured at $578 \mathrm{~nm}$ on a multidetection microplate reader. Cytotoxicity was expressed as the percentage of viable cells compared with that of the untreated control cells.

4.9. Chemo-PTT in Vitro of nPANI@nZIF-8/5-FU. To evaluate the therapeutic effect of nPANI@nZIF-8/5-FU, MCF7 cells were seeded into a 96-well plate with a density of $1 \times 10^{4}$ cells per well. The wells were divided into five teams which were termed as follows: control, nPANI@nZIF-8 (125 and $250 \mu \mathrm{g} / \mathrm{mL}), \mathrm{nPANI} @ \mathrm{nZIF-8} / 5-\mathrm{FU}$ (125 and 250 $\mu \mathrm{g} /$ $\mathrm{mL})$, and nPANI@nZIF-8/5-FU + NIR (125 and 250 $\mu \mathrm{g} /$ $\mathrm{mL})$. The cells were then incubated for $72 \mathrm{~h}$. Subsequently, nPANI@nZIF-8/5-FU + NIR were further irradiated by the NIR laser $\left(\lambda=980 \mathrm{~nm}, 0.8 \mathrm{~W} \mathrm{~cm}^{-2}\right)$ for $5 \mathrm{~min}$. After irradiation, $20 \mu \mathrm{L}$ of MTT $\left(0.5 \mathrm{mg} \mathrm{mL}^{-1}\right)$ was added in each well, and the cells were incubated for another $3 \mathrm{~h}$ to measure the cell viability.

4.10. Statistical Analysis. The data were expressed as mean \pm SD. Statistical analysis was performed using STATISTICA 8 by the Student's $t$-test. $* P<0.05$ was considered significant, and $* * P<0.01$ was considered highly significant.

\section{ASSOCIATED CONTENT}

\section{Supporting Information}

The Supporting Information is available free of charge on the ACS Publications website at DOI: 10.1021/acsomega.8b01067.

XRD analysis, $\mathrm{N}_{2}$ adsorption-desorption measurements, and TEM analysis for the in situ synthesis of the network nZIF-8 in $50 \mathrm{v} / \mathrm{v} \%$ of the PANI solution and methanol, and adsorption kinetics curve for nPANI@nZIF-8 used as the carrier for the 5-FU drug (PDF)

\section{AUTHOR INFORMATION}

\section{Corresponding Author}

*E-mail: salvesjr@ufpe.br (S.A.J.).

ORCID ${ }^{\circ}$

Célia M. Ronconi: 0000-0001-9736-9661

Severino A. Júnior: 0000-0002-8092-4224

\section{Notes}

The authors declare no competing financial interest.

The English text of this paper has been revised by Sidney Pratt, Canadian, MAT (The Johns Hopkins University), RSAdipTESL (Cambridge University).

\section{ACKNOWLEDGMENTS}

This work was supported by CETENE, CAPES, and CNPq. The authors gratefully acknowledge the laboratory BSTR for their support.

\section{REFERENCES}

(1) Cao, J.; Chen, D.; Huang, S.; Deng, D.; Tang, L.; Gu, Y. Multifunctional near-infrared light-triggered biodegradable micelles for chemo- and photo-thermal combination therapy. Oncotarget 2016, 7,82170 .

(2) Yang, X.; Li, L.; He, D.; Hai, L.; Tang, J.; Li, H.; He, X.; Wang, K. A metal-organic framework based nanocomposite with coencapsulation of Pd@Au nanoparticles and doxorubicin for pH- and NIR-triggered synergistic chemo-photothermal treatment of cancer cells. J. Mater. Chem. B 2017, 5, 4648.

(3) He, M.; Zhou, J.; Chen, J.; Zheng, F.; Wang, D.; Shi, R.; Guo, Z.; Wang, H.; Chen, Q. Fe3O4@carbon@zeolitic imidazolate framework8 nanoparticles as multifunctional $\mathrm{pH}$-responsive drug delivery vehicles for tumor therapy in vivo. J. Mater. Chem. B 2015, 3, 9033-9042.

(4) Tian, Z.; Yao, X.; Zhu, Y. Simple synthesis of multifunctional zeolitic imidazolate frameworks-8/graphene oxide nanocrystals with controlled drug release and photothermal effect. Microporous Mesoporous Mater. 2017, 237, 160-167.

(5) Wu, L.; Wu, M.; Zeng, Y.; Zhang, D.; Zheng, A.; Liu, X.; Liu, J. Multifunctional PEG modified DOX loaded mesoporous silica nanoparticle@CuS nanohybrids as photo-thermal agent and thermal-triggered drug release vehicle for hepatocellular carcinoma treatment. Nanotechnology 2015, 26, 025102.

(6) Chen, H.; Di, Y.; Chen, D.; Madrid, K.; Zhang, M.; Tian, C.; Tang, L.; Gu, Y. Combined chemo- and photo-thermal therapy delivered by multifunctional theranostic gold nanorod-loaded microcapsules. Nanoscale 2015, 7, 8884-8897.

(7) Wang, K.; Chen, Q.; Xue, W.; Li, S.; Liu, Z. Combined Chemophotothermal Antitumor Therapy Using Molybdenum Disulfide Modified with Hyperbranched Polyglycidyl. ACS Biomater. Sci. Eng. 2017, 3, 2325-2335.

(8) Zhu, Y.-D.; Chen, S.-P.; Zhao, H.; Yang, Y.; Chen, X.-Q.; Sun, J.; Fan, H.-S.; Zhang, X.-D. PPy@MIL-100 Nanoparticles as a pH- and Near-IR-Irradiation-Responsive Drug Carrier for Simultaneous Photo- 
thermal Therapy and Chemotherapy of Cancer Cells. ACS Appl. Mater. Interfaces 2016, 8, 34209.

(9) Huff, T. B.; Tong, L.; Zhao, Y.; Hansen, M. N.; Cheng, J.-X.; Wei, A. Hyperthermic effects of gold nanorods on tumor cells. Nanomedicine 2007, 2, 125-132.

(10) Jaque, D.; Martínez Maestro, L.; del Rosal, B.; Haro-Gonzalez, P.; Benayas, A.; Plaza, J. L.; Martín Rodríguez, E.; García Solé, J. Nanoparticles for photothermal therapies. Nanoscale 2014, 6, 94949530.

(11) Yang, D.; Yang, G.; Gai, S.; He, F.; An, G.; Dai, Y.; Lv, R.; Yang, P. Au25 cluster functionalized metal-organic nanostructures for magnetically targeted photodynamic/photothermal therapy triggered by single wavelength $808 \mathrm{~nm}$ near-infrared light. Nanoscale 2015, 7, 19568-19578.

(12) Tian, Q.; Jiang, F.; Zou, R.; Liu, Q.; Chen, Z.; Zhu, M.; Yang, S.; Wang, J.; Wang, J.; Hu, J. Hydrophilic $\mathrm{Cu}_{9} \mathrm{~S}_{5}$ Nanocrystals: A Photothermal Agent with a $25.7 \%$ Heat Conversion Efficiency for Photothermal Ablation of Cancer Cells in Vivo. ACS Nano 2011, 5, 9761.

(13) Huang, X.; Tang, S.; Liu, B.; Ren, B.; Zheng, N. Enhancing the photothermal stability of plasmonic metal nanoplates by a core-shell architecture. Adv. Mater. 2011, 23, 3420-3425.

(14) Tian, Q.; Tang, M.; Sun, Y.; Zou, R.; Chen, Z.; Zhu, M.; Yang, S.; Wang, J.; Wang, J.; Junqing, H. Hydrophilic flower-like CuS superstructures as an efficient $980 \mathrm{~nm}$ laser-driven photothermal agent for ablation of cancer cells. Adv. Mater. 2011, 23, 3542-3547. (15) Zhou, J.; Lu, Z.; Zhu, X.; Wang, X.; Liao, Y.; Ma, Z.; Li, F. NIR photothermal therapy using polyaniline nanoparticles. Biomaterials 2013, 34, 9584-9592.

(16) Chiang, W.-L.; Lin, T.-T.; Sureshbabu, R.; Chia, W.-T.; Hsiao, H.-C.; Liu, H.-Y.; Yang, C.-M.; Sung, H.-W. A rapid drug release system with a NIR light-activated molecular switch for dual-modality photothermal/antibiotic treatments of subcutaneous abscesses. J. Controlled Release 2015, 199, 53.

(17) Wang, M. Emerging Multifunctional NIR Photothermal Therapy Systems Based on Polypyrrole Nanoparticles. polymers 2016, 8, 373.

(18) Chen, X.; Zhang, M.; Li, S.; Li, L.; Zhang, L.; Wang, T.; Yu, M.; Mou, Z.; Wang, C. Facile synthesis of polypyrrole@metal-organic framework core-shell nanocomposites for dual-mode imaging and synergistic chemo-photothermal therapy of cancer cells. J. Mater. Chem. B 2017, 5, 1772-1778.

(19) Mazrad, Z. A. I.; Choi, C. A.; Kim, S. H.; Lee, G.; Lee, S.; In, I.; Lee, K.-D.; Park, S. Y. Target-specific induced hyaluronic acid decorated silica fluorescent nanoparticles@polyaniline for bio-imaging guided near-infrared photothermal therapy. J. Mater. Chem. B 2017, 5, 7099-7108.

(20) Chen, H.; Liu, Z.; Li, S.; Su, C.; Qiu, X.; Zhong, H.; Guo, Z. Fabrication of Graphene and AuNP Core Polyaniline Shell Nanocomposites as Multifunctional Theranostic Platforms for SERS Realtime Monitoring and Chemo-photothermal Therapy. Theranostics 2016, 6, 1096-1104.

(21) Bhadra, S.; Khastgir, D.; Singha, N. K.; Lee, J. H. Progress in preparation, processing and applications of polyaniline. Prog. Polym. Sci. 2009, 34, 783-810.

(22) Yao, X.; Tian, Z.; Liu, J.; Zhu, Y.; Hanagata, N. Mesoporous Silica Nanoparticles Capped with Graphene Quantum Dots for Potential Chemo-Photothermal Synergistic Cancer Therapy. Langmuir 2017, 33, 591-599.

(23) Xu, Y.; Zhu, Y.; Kaskel, S. A smart magnetic nanosystem with controllable drug release and hyperthermia for potential cancer therapy. RSC Adv. 2015, 5, 99875-99883.

(24) Yao, X.; Niu, X.; Ma, K.; Huang, P.; Grothe, J.; Kaskel, S.; Zhu, Y. Graphene Quantum Dots-Capped Magnetic Mesoporous Silica Nanoparticles as a Multifunctional Platform for Controlled Drug Delivery, Magnetic Hyperthermia, and Photothermal Therapy. Small 2017, 13, 1602225 .
(25) Öhrström, L. Let's Talk about MOFs-Topology and Terminology of Metal-Organic Frameworks and Why We Need Them. Crystals 2015, 5, 154-162.

(26) Rowsell, J. L. C.; Yaghi, O. M. Metal-organic frameworks: a new class of porous materials. Microporous Mesoporous Mater. 2004, 73, 314.

(27) James, S. L. Metal-organic frameworks. Chem. Soc. Rev. 2003, 32, 276.

(28) Vasconcelos, I. B.; da Silva, T. G.; Militão, G. C. G.; Soares, T. A.; Rodrigues, N. M.; Rodrigues, M. O.; da Costa, N. B., Jr.; Freire, R. O.; Junior, S. A. Cytotoxicity and slow release of the anti-cancer drug doxorubicin from ZIF-8. RSC Adv. 2012, 2, 9437.

(29) Rodrigues, M. O.; de Paula, M. V.; Wanderley, K. A.; Vasconcelos, I. B.; Soares, S.; Soares, T. A. Metal organic frameworks for drug delivery and environmental remediation: A molecular docking approach. Quantum Chem. 2012, 112, 3346-3355.

(30) He, C.; Liu, D.; Lin, W. Nanomedicine Applications of Hybrid Nanomaterials Built from Metal-Ligand Coordination Bonds: Nanoscale Metal-Organic Frameworks and Nanoscale Coordination Polymers. Chem. Rev. 2015, 115, 11079-11108.

(31) Tian, T.-Q.; Cai, C.-X.; Ren, X.-M.; Duan, C.-Y.; Xu, Y.; Gao, S.; You, X.-Z. The Silica-Like Extended Polymorphism of Cobalt(II) Imidazolate Three-Dimensional Frameworks: X-ray Single-Crystal Structures and Magnetic Properties. Chem.-Eur. J. 2003, 9, 5673.

(32) Huang, X.-C.; Lin, Y.-Y.; Zhang, J.-P.; Chen, X.-M. Liganddirected strategy for zeolite-type metal-organic frameworks: zinc(II) imidazolates with unusual zeolitic topologies. Angew. Chem., Int. Ed. 2006, 45, 1557-1559.

(33) Park, K. S.; Ni, Z.; Côté, A. P.; Choi, J. Y.; Huang, R.; UribeRomo, F. J.; Chae, H. K.; O'Keeffe, M.; Yaghi, O. M. Exceptional chemical and thermal stability of zeolitic imidazolate frameworks. Proc. Natl. Acad. Sci. U.S.A. 2006, 103, 10186-10191.

(34) Hayashi, H.; Côté, A. P.; Furukawa, H.; O’Keeffe, M.; Yaghi, O. M. Zeolite A imidazolate frameworks. Nat. Mater. 2007, 6, 501-506.

(35) Tian, Z.; Yao, X.; Ma, K.; Niu, X.; Grothe, J.; Xu, Q.; Liu, L.; Kaskel, S.; Zhu, Y. Metal-Organic Framework/Graphene Quantum Dot Nanoparticles Used for Synergistic Chemo- and Photothermal Therapy. ACS Omega 2017, 2, 1249-1258.

(36) Chowdhuri, A. R.; Laha, D.; Pal, S.; Karmakar, P.; Sahu, S. K. One-pot synthesis of folic acid encapsulated upconversion nanoscale metal organic frameworks for targeting, imaging and $\mathrm{pH}$ responsive drug release. Dalton Trans. 2016, 45, 18120-18132.

(37) Lu, G.; Li, S.; Guo, Z.; Farha, O. K.; Hauser, B. G.; Qi, X.; Wang, Y.; Wang, X.; Han, S.; Liu, X.; DuChene, J. S.; Zhang, H.; Zhang, Q.; Chen, X.; Ma, J.; Loo, S. C. J.; Wei, W. D.; Yang, Y.; Hupp, J. T.; Huo, F. Imparting functionality to a metal-organic framework material by controlled nanoparticle encapsulation. Nat. Chem. 2012, 4, 310-316.

(38) Jozefowicz, M. E.; Laversanne, R.; Javadi, H. H. S.; Epstein, A. J.; Pouget, J. P.; Tang, X.; MacDiarmid, A. G. Multiple lattice phases and polaron-lattice-spinless-defect competition in polyaniline. Phys. Rev. B: Condens. Matter Mater. Phys. 1989, 39, 12958-12961.

(39) Pouget, J. P.; Jozefowicz, M. E.; Epstein, A. J.; Tang, X.; MacDiarmid, A. G. X-ray structure of polyaniline. Macromolecules 1991, 24, 779-789.

(40) Chen, Y.; Li, C.; Hou, Z.; Huang, S.; Liu, B.; He, F.; Luo, L.; Lin, J. Polyaniline electrospinning composite fibers for orthotopic photothermal treatment of tumors in vivo. New J. Chem. 2015, 39, 4987-4993.

(41) Schejn, A.; Mazet, T.; Falk, V.; Balan, L.; Aranda, L.; Medjahdi, G.; Schneider, R. Fe3O4@ZIF-8: magnetically recoverable catalysts by loading $\mathrm{Fe} 3 \mathrm{O} 4$ nanoparticles inside a zinc imidazolate framework. Dalton Trans. 2015, 44, 10136-10140.

(42) Jing, H.-P.; Wang, C.-C.; Zhang, Y.-W.; Wang, P.; Li, R. Photocatalytic degradation of methylene blue in ZIF-8. RSC Adv. 2014, 4, 54454-54462.

(43) Ordoñez, M. J. C.; Balkus, K. J., Jr.; Ferraris, J. P.; Musselman, I. H. Molecular sieving realized with ZIF-8/Matrimid mixed-matrix membranes. J. Membr. Sci. 2010, 361, 28-37. 
(44) Morsi, R. E.; Elsabee, M. Z. Polyaniline Nanotubes: Mercury and Competitive Heavy Metals Uptake. Am. J. Polym. Sci. 2015, 5, 10. (45) Huang, W.-S.; Humphrey, B. D.; MacDiarmid, A. G. Polyaniline, a novel conducting polymer. Morphology and chemistry of its oxidation and reduction in aqueous electrolytes. J. Chem. Soc., Faraday Trans. 1 1986, 82, 2385.

(46) Sun, C.-Y.; Qin, C.; Wang, X.-L.; Yang, G.-S.; Shao, K.-Z.; Lan, Y.-Q.; Su, Z.-M.; Huang, P.; Wang, C.-G.; Wang, E.-B. Zeolitic imidazolate framework-8 as efficient $\mathrm{pH}$-sensitive drug delivery vehicle. Dalton Trans. 2012, 41, 6906.

(47) Gao, X.; Hai, X.; Baigude, H.; Guan, W.; Liu, Z. Fabrication of functional hollow microspheres constructed from MOF shells: Promising drug delivery systems with high loading capacity and targeted transport. Sci. Rep. 2016, 6, 37705.

(48) Pan, Y.; Liu, Y.; Zeng, G.; Zhao, L.; Lai, Z. Rapid synthesis of zeolitic imidazolate framework-8 (ZIF-8) nanocrystals in an aqueous system. Chem. Commun. 2011, 47, 2071.

(49) Olukman, M.; Şanlı, O.; Solak, E. K. Release of Anticancer Drug 5-Fluorouracil from Different Ionically Crosslinked Alginate Beads. J. Biomater. Nanobiotechnol. 2012, 3, 469-479.

(50) Kim, B.-J.; Oh, S.-G.; Han, M.-G.; Im, S.-S. Synthesis and characterization of polyaniline nanoparticles in SDS micellar solutions. Synth. Met. 2001, 122, 297.

(51) Roper, D. K.; Ahn, W.; Hoepfner, M. Microscale Heat Transfer Transduced by Surface Plasmon Resonant Gold Nanoparticles. J. Phys. Chem. C 2007, 111, 3636-3641.

(52) Ray Chowdhuri, A.; Tripathy, S.; Haldar, C.; Roy, S.; Sahu, S. K. Single step synthesis of carbon dot embedded chitosan nanoparticles for cell imaging and hydrophobic drug delivery. J. Mater. Chem. B 2015, 3, 9122-9131. 